\title{
A Study of the Adsorptive and Oxidative Bleaching of Palm Oil Using Clay and Potassium Tetraoxomanganate V11 Materials
}

\author{
A. M. Ekwonu' ${ }^{1}$, E. O. Egolum ${ }^{2}$ \\ ${ }^{1}$ Department of Pure and Industrial Chemistry, Anambra State University, Uli. Nigeria. \\ ${ }^{2}$ Department of Chemistry, Nwafor Orizu College of Education, Nsugbe, Anambra State. Nigeria \\ Correspondence: E. O. Egolum, Department of Chemistry, Nwafor Orizu College of Education, Nsugbe, Anambra State. \\ Nigeria.
}

Received: August 29, 2016 Accepted: February 6, 2017 Online Published:April 17, 2017

doi:10.5539/ijc.v9n2p67

URL: https://doi.org/10.5539/ijc.v9n2p67

\begin{abstract}
Fats and oils undergo hydrolysis reaction. They hydrolyse to yield propane-1,2,3 triol and the corresponding alkanoic acids if it is acid hydrolysis. Alkaline hydrolysis yields sodium or potassium salt of the alkanoic acid and propane-1,2,3-triol. A common approach for bleaching palm oil has been the use of clay materials, particularly the commercially available fuller's earth. In this study, the suitability of chemical bleaching of palm oil using acidified $\left(0.1 \mathrm{M} \mathrm{H}_{2} \mathrm{SO}_{4}\right)$ and non-acidified $1.0 \mathrm{M} \mathrm{KMnO}_{4}$ was examined. This is compared to the adsorptive procedure using clay materials. Average bleaching absorbance values of $0.017+0.005$ and $0.115 \pm 0.004$ for acidified and non-acidified $\mathrm{KMnO}_{4}$ were respectively obtained from the oxidative bleaching procedure. Those for fuller's earth and its blend with sodium sesquicarbonate (trona, a locally obtained clay) gave absorbance values of $0.121 \pm 0.011$ and $0.186 \pm 0.006$ respectively; while that for trona/activated carbon blend was $0.234+0.007$. These are in comparison to 0.881 for the unbleached palm oil. Thus, a relatively better bleaching was achieved with the oxidative process. A first order rate reaction with respect to the bleaching agents was obtained for both procedures. Rate constants of $0.079 \pm 014$ (acidified) and $0.055 \pm 0.020 \mathrm{~min}^{-1}$ (non-acidified) at $80^{\circ} \mathrm{C}$ were recorded for the oxidative bleaching. These are compared to $0.034 \pm 0.009$ obtained for the clay mixture. Half-life values of $10 \mathrm{~min}$ for acidified oxidative process, and $28 \mathrm{~min}$ for adsorptive clay mixture method, were obtained. Efficiency of $98 \%$ was obtained for the acidified oxidative compared to approximately $70 \%$ for the clay blend. A significance, $\mathrm{p} \leq 0.05$, between the absorbance values for the acidified oxidative and each of the adsorptive clay bleaching procedures was obtained.These observations indicate the potentials of oxidizing agents especially the acidified $\mathrm{KMnO}_{4}$ in the bleaching of palm oil, and therefore, suggest its usage industrially for this purpose.
\end{abstract}

Keywords: palm oil, adsorptive, oxidative, bleaching, clay and $\mathrm{KMnO}_{4}$ materials

\section{Introduction}

Fats and oils are mixtures of various alkanoates (esters) formed by the union of three molecules of long carbon-chain alkanoic acids (fatty acids or carboxylic acids) with one molecule of a trihydric alkanol called propane-1,2,3-triol (glycerol) (Philip Matthews, 2004).

Palm oil is formed by the reaction of hexadeconoic acid (palmitic acid) and ethylhydroxide $\left(\mathrm{CH}_{2} \mathrm{OH}\right)$ producing a pamitate (Philip Matthews, 2004), represented as below:

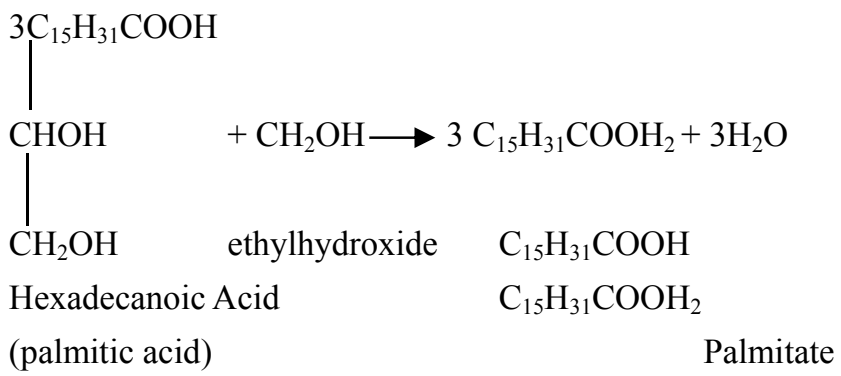

Bleaching of palm oil serve as a means of enhancing its industrial utilization. Adsorptive bleaching process utilizing clays particularly the commercially available Fuller's earth and locally obtained sodium sesquicarbonate (trona), and 
activacted carbon has been a common process (Gregg and Sing, 1967). Odoemelam (Odoemelam,1998) examined the use of several locally sourced clay materials in the bleaching of palm oil.

This study seeks to investigate the oxidative process using acidified and non-acidified $\mathrm{KMnO}_{4}$ as the oxidants as has been reported (Ogugbuaja and Akpomie, 2003) in comparison to the commonly used fuller's earth, and 40:60 mixture ratio of Fuller's earth to trona. The oxidative potential of acidified $\mathrm{KMnO}_{4}$ is well known and has been utilized in several oxidizing processes. The amenability of this oxidative procedure, which might be of industrial application, is of research interest.

\section{Materials and Methods}

\subsection{Materials Used and Their Sources}

Raw palm oil sample and trona (sodum sesquicarbonate) were obtained from uruekwo village, Enugu-Ukwu in Anambra State. Activated carbon (made in Thailand) and Fuller's earth (Fulmont type A) were obtained from Godwin-Kris rubber industries, Nnewi Anambra State, Nigeria. The materials were kept in a refrigerator until when needed.

\subsection{Extraction Method and Analytical Procedure}

\subsubsection{Palm Oil Sample Purification and $\lambda$ max Determination}

Some quantity of the palm oil was filtered by suction. A portion of the filtrate, $0.1 \mathrm{ml}$, was diluted with $20 \mathrm{ml}$ cyclohexane as has earlier been reported according to (Ogugbuaja and Akpomie, 2003). The maximum wavelength, $\lambda \max$, was determined as 460nm using GENWAY $6300 \mathrm{UV}$ spectrophotometer. The $\mathrm{pH}$ of the palm oil was obtained as 4.6 using standard procedure (Ogugbuaja, 2000).

\subsubsection{Bleaching of Palm Oil}

In a typical palm oil bleaching by clay adsorption process, $5 \mathrm{~g}$ each, of fuller's earth, $60: 40$ (3g to $2 \mathrm{~g}$ portions) of trona to fuller's earth ratio and trona to activated carbon were used. In case of the oxidative bleaching process, $20 \mathrm{ml} 1.0 \mathrm{M}$ $\mathrm{KMnO}_{4}$ acidified with $1.0 \mathrm{ml} 0.1 \mathrm{M} \mathrm{H}_{2} \mathrm{SO}_{4}$ and non-acidified $\mathrm{KMnO}_{4}$ were used. For the bleaching process, $50 \mathrm{~g}$ aliquots of filtered fresh palm oil samples were added to each of the bleaching agents. The mixtures were placed in a water bath thermostated at $80^{\circ} \mathrm{C}$ and stirred continuously for $60 \mathrm{~min}$ and then left to cool. After cooling, and filtering by suction, their absorbance values were determined. Replicates of all these were carried out and the average absorbance values of each recorded as a function of time. The absorbance of the unbleached palm oil was determined as 0.881 .

\subsection{Kinetics Study}

The order of reaction, and rate constants of the bleaching processes were determined at $60 \mathrm{~min}$ and $80^{\circ} \mathrm{C}$ by using appropriate formula and graphical evaluation procedure as reported in (J.O. Nwadiogbu et all, (2014).

\section{Results}

The result obtained in this research were presented in tables 1, 2 and 3 below:

Table 1. Absorbance values of bleaching $50 \mathrm{~g}$ of palm oil using bleaching agent of potassium tetraoxomanganate $\left(\mathrm{KMnO}_{4}\right)$ vii

\begin{tabular}{lllll}
\hline $\mathrm{S} / \mathrm{N}$ & Sample & \multicolumn{3}{c}{ Bleaching Agent } \\
\cline { 2 - 5 } & Fullers earth & Fullers & earth/Trona & 1.0M KMnO4 \\
& & $40: 60$ & Acidified & Non acidified \\
1 & 0.116 & 0.181 & 0.014 & 0.112 \\
2 & 0.114 & 0.184 & 0.018 & 0.116 \\
3 & 0.116 & 0.194 & 0.024 & 0.114 \\
4 & 0.138 & 0.186 & 0.014 & 0.121 \\
5 & & & 0.013 & 0.110 \\
Mean & $0.121+0.01$ & $0.186+0.00$ & $0.017+0.00$ & $0.115+0.00$ \\
& 1a & $6 \mathrm{~b}$ & $5 \mathrm{c}$ & $4 \mathrm{a}$ \\
\hline
\end{tabular}

* Mean values with different letters are statistically different at 95\% confidence level. 
Table 2. Absorbance Values of bleaching 50g of Palm Oil using Bleaching agent of Trona/Activated carbon

\begin{tabular}{|c|c|c|c|}
\hline \multirow[t]{2}{*}{$\mathrm{S} / \mathrm{N}$} & \multicolumn{2}{|l|}{ Sample } & Bleaching Agent \\
\hline & Fullers earth & $\begin{array}{l}\text { Fullers earth/Trona } \\
40: 60\end{array}$ & Trona/Activated carbon \\
\hline 1 & 0.116 & 0.181 & 0.242 \\
\hline 2 & 0.114 & 0.184 & 0.228 \\
\hline 3 & 0.116 & 0.194 & 0.236 \\
\hline 4 & 0.138 & 0.186 & 0.226 \\
\hline 5 & & & \\
\hline Mean & $\begin{array}{l}0.121+0.01 \\
1 \mathrm{a}\end{array}$ & $\begin{array}{l}0.186+0.00 \\
6 b\end{array}$ & $\begin{array}{l}0.234+0.00 \\
7 \mathrm{~d}\end{array}$ \\
\hline
\end{tabular}

* Mean values with different letters are statistically different at $\mathbf{9 5 \%}$ confidence level.

Table 3. Kinetics studies absorbance values and rate constants data, of bleaching of $50 \mathrm{~g}$ palm oil at $80 \mathrm{oC}$ using clays (adsorptive) and KMno4 (oxidative) bleaching agents

\begin{tabular}{|c|c|c|c|c|c|c|}
\hline \multirow[t]{2}{*}{$\begin{array}{l}\text { Time } \\
(\min )\end{array}$} & \multicolumn{2}{|l|}{$\begin{array}{l}\text { Bleaching agents } \\
\text { A }\end{array}$} & \multicolumn{2}{|l|}{ B } & \multicolumn{2}{|l|}{$\mathrm{C}$} \\
\hline & $\mathrm{Ab}_{\mathrm{A}}$ & $\mathrm{K}_{\mathrm{A}}$ & $\mathrm{Ab}_{\mathrm{B}}$ & $\mathrm{K}_{\mathrm{B}}$ & $\mathrm{Ab}_{\mathrm{c}}$ & $\mathrm{K}_{\mathrm{C}}$ \\
\hline 10 & 0.601 & 0.051 & - & - & - & - \\
\hline 20 & 0.512 & 0.030 & 0.174 & 0.086 & 0.125 & 0.104 \\
\hline 30 & 0.334 & 0.036 & 0.155 & 0.062 & 0.106 & 0.075 \\
\hline 40 & 0.302 & 0.030 & 0.131 & 0.051 & 0.048 & 0.076 \\
\hline 50 & 0.261 & 0.027 & 0.129 & 0.041 & 0.030 & 0.070 \\
\hline 60 & 0.181 & 0.028 & 0.112 & 0.036 & 0.014 & 0.071 \\
\hline Mean & $0.034+0.009$ & & $0.055 \pm 0.020$ & & $0.079 \pm 0.014$ & \\
\hline
\end{tabular}

Key: $\mathrm{A}=60: 40$ ratio of trona: fullers earth; $\mathrm{B}=$ non acidified and $\mathrm{C}=$ acidified $\mathrm{KMnO} 4 \mathrm{~K}=$ the respective rate constants (min-1); $\mathrm{Ab}=$ absorbance.

From the table of result in 1,2 and 3, the plots of $\log$ A versus time were plotted and shown in graphs as figures 1-3 as follows:

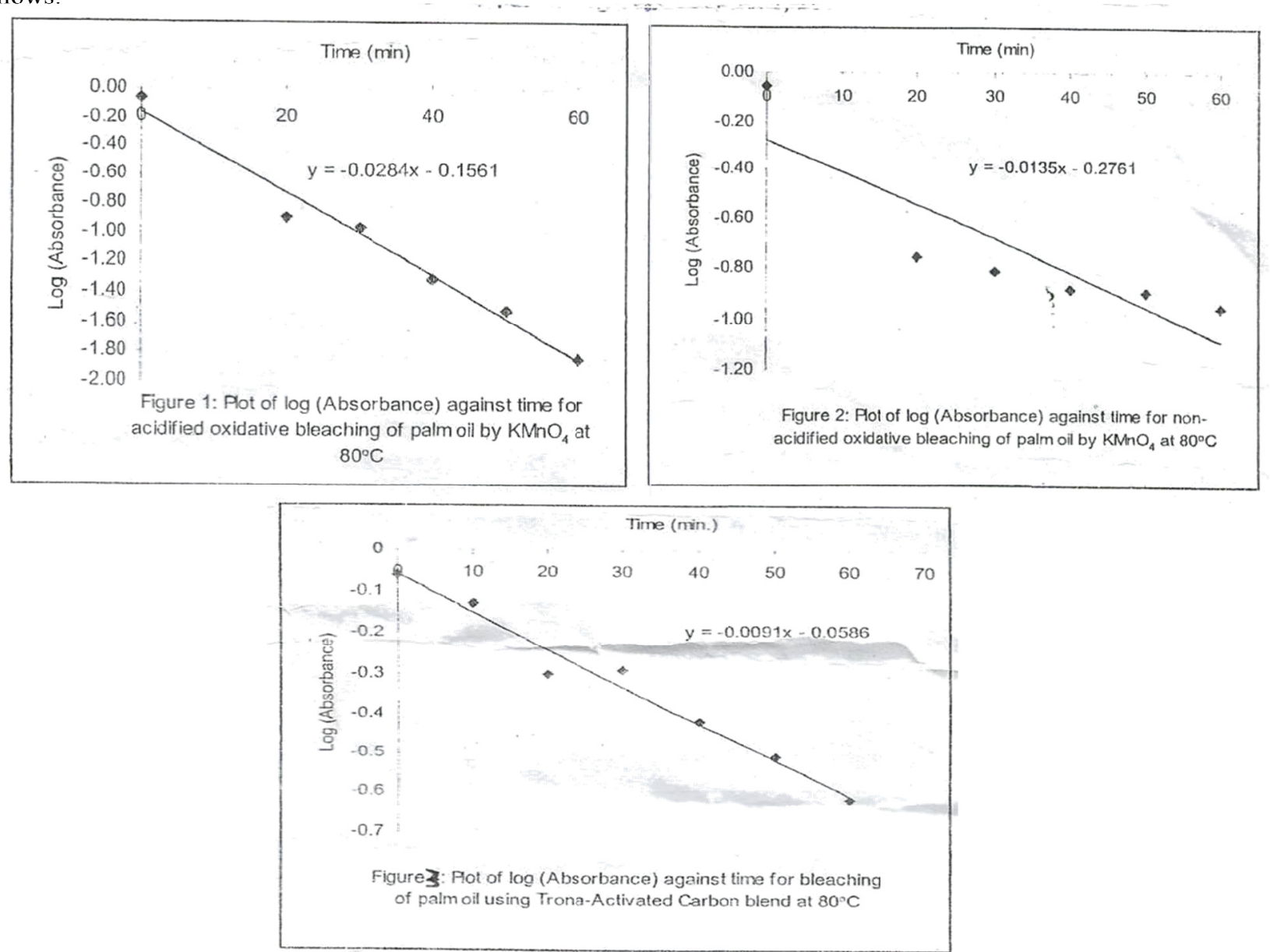




\section{Discussion}

Mean absorbance values for the four bleaching agents used are presented in table 1, respective values of $0.121 \pm 0.011$, $0.186 \pm 0.006,0.017 \pm 0.005$ and $0.151 \pm 0.004$ were recorded for the fuller's earth, trona:/fuller's earth blend, the acidified and non-acidified oxidation processes using $\mathrm{KMnO}$. The bleaching agent of trona/activated carbon in table 2 also recorded, and the mean absorbance value of $0.234 \pm 0.007$ was obtained.

In table 1, it is evident that more efficient bleaching was obtained from the use of acidified $\mathrm{KMnO} 4$; up to $98 \%$ bleaching efficiency was obtained from this oxidative procedure. This is as compared to $86 \%$ for Fuller's earth and about $70 \%$ for the trona blends. Statistically, there was a significant difference $(p \leq 0.05)$ between the results for the acidified oxidation and the other processes. However, no statistical difference existed between the results for the fuller's earth and the non-acidified $\mathrm{KMnO}_{4}$ bleaching processes at $\mathrm{p} \leq 0.05$.

The adsorptive bleaching process by clay materials is a surface phenomenon according to J.O. Nwadiogbu et,al, (2015) This is noted to be dependent on the apparent bulk density (ABD), the moisture content,

particle size, loss on ignition, and acidity of the oil. These characteristics collectively play some roles in the bleaching capacity of clays. KMnO4 solution on the other hand selectively destroys the unsaturated structure of the B-carotene responsible for the red colouring pigmentation of palm oil. These factors are separately responsible for the bleaching of palm oil either by adsorptive or oxidative process. These capabilities were exploited in the kinetics studies of the bleaching processes in each case.

The plots of Log A versus time were plotted and shown in graphs. Figure 1 shows the plot of log (Absorbance) against time for acidified oxidative bleaching of palm oil by $\mathrm{KMn}_{4}$ at $80^{\circ \mathrm{c}}$ with slope of $\mathrm{y}=0.0284 \mathrm{x}-0.1561$. Figure 2 shows the plot of $\log$ (absorbance) against time for non-acidified bleaching of palm oil by $\mathrm{KMn}_{4}$ at $80^{0 \mathrm{c}}$ with slope of $\mathrm{y}=$ $0.0135 \mathrm{x}-0.2761$ and figure 3 shows the plot of (Absorbance) against time for bleaching of palm oil using Trona/Activate carbon blend at $80^{0 \mathrm{cc}}$ with slope of $\mathrm{y}=0.0091 \mathrm{x}-0.0586$ respectively.

A first order reaction with respect to the adsorbent and the oxidant was obtained for each case. The relevant equation used for the calculation of pertinent kinetic parameters is given as $\log \left(\mathrm{B}_{t} / \mathrm{B}_{0}\right)=-\mathrm{Kt} / 2.303$, where $\mathrm{B}$ represents the absorbance values of the bleaching agents at times $t$ and

zero respectively. The number of adsorptive sites in the clay materials and $\mathrm{pH}$ of the oxidants influenced the rate of reaction. The plots of $\log \mathrm{A}$ versus time are shown in figures 1.3. From the graphs a first order reaction is predicted. Table 3 shows the kinetics data obtained from these plots. Rate constants of $7.9 \times 10^{-2} \pm 1.4 \times 10^{-2} \mathrm{~min}^{-1}$ for the acidified $\mathrm{KMnO}_{4}, 5.5 \times 10^{-2} \pm 2.0 \times 10^{-2}$ for non acidified KMnO4, 3.4 $\times 10^{-2} \pm 9.0 \times 10^{-3} \mathrm{~min}^{-1}$ for the trona/fullers earth blend, and $2.1 \times 10^{-2}$ for trona/activated carbon blend were obtained.

\section{Conclusion}

The acidified potassium tetraoxomanganate vii $\left(\mathrm{KMnO}_{4}\right)$ oxidative process had a higher bleaching efficiency than clay materials used in this study. In addition, the comparably short half-life of $10 \mathrm{~min}$ obtained suggests that the oxidative process is better for the bleaching of palm oil. Acidified $\mathrm{KMnO}_{4}$ is therefore recommended for industrial bleaching of palm oil.

\section{References}

Avory, H. E. (1982). Basic Reaction Kinetics and Mechanisms. The Macmillan press Ltd., London, 11-14.

Choi, H. M., \& Cloud, R. N. (1999). Natural Sorbents in oil spill cleanup, Environ. Sn. Technol, 26(4), 772-776.

Daniel, F., \& Alberty, R. A. (1975). Physical Chemistry Textbook. Cambridge university, massachrisetts pp 605-643

Davies, J. T., \& Rideal, E. K. (1963). Interfacial phenomena, studies and properties of surfaces and interfaces in liquid system. Academic press, Inc. New York.

Dawodu, F. A., \& Akpomie, K. G. (2014). simultaneous adsorption of Ni (11) and Mbn (11) ions from aqueous solutions unto a Nigerian Kaolinite clay, J. mater. Res. Technol, 3(2), 129-141.

Dougles, A. S. (1985). principles of instrumental Analysis (3 $3^{\text {rd }}$ edition ) ISBN 0-03-001229-5 Standford university or lando, florida sannders college publishing Holt, Rinehart and Winston. U.S.A.

Gordopm, M. B. (1979). physical chemistry textbook International student edition by Mc Graw-Hill, Kogakusha, Ltd., tokoyo, Japan, 739-742.

Gregg, S., \& Sing, K. (1969). Adsorption, surface Area and porosity. Academic press, Inc., New York.

Latham, J. L. (1969). Elementary Reaction Kinetics and Mechanism, The macmillan press Ltd. London, 11-14. 
Nayward, O. O., \& Trapnell, M. B. W. (1964). An excellent summary of the present state of our knowledge of the rates, equilibrium pressures, heats and mechanisms involved in the chemisorption of gases on solids "Chemisorption", $2^{\text {nd }}$ edition Bulterworth \& co.w.Lond. Odoemelam, S.A .(1998) J.Chem. Soc. Nigeria, 23, 32-34.

Nwadiogbu, J. O. P. A. C., Okoye, V. I. E., \& Ajiwe, J. N. S. N. (2014). Hydrophobic treatment of corn cob by acetylation: Kinetic and thermodynamic studies. J. Environ Chem. Eng., 2, 1699-1705.

https://doi.org/10.1016/j.jece.2014.06.003

Nwadiogbu, J. O. V. I. C., \& Ajiwe, P. A. C. O. (2015). Removal of crude oil from aqueous medium by sorption on hydrophobic corncobs: Equilibrium and Kinetics, Journal of Taibah University for Science, 10(2016), 56-63. https://doi.org/10.1016/j.jtusci.2015.03.014

Ogugbuaja, V. O. (2000). Adsorption (Emission spectroscopy: An instrumental methodology in Andytical chemistry publ. The faculty of Science University, Maiduguri, 20-21.

Ogugbuaja, V. O., \& Akpomie, T. M. (2003). Oxidative bleaching of palm oil using $\mathrm{KMNO}_{4}$ J. Arid Agric. (in press)

Ojo, J. O., \& Adeeyinwo, C. E. (2011). Dependence of venadium recovery on oxidation state in its solvent extraction from hydrochloric acid solutions with tri tri-n-butyl phosphate. Ife journal of science, 31(1), 175-184.

Ojo, J. O., Ipinmoroti, K. O., \& Adeeyiinwo, C. E. (2007). Kinetics and Mechanisms of V(v) extraction form hydrochloric acid and solutions with tri-n-butyl phosphate. Journal of chemical society of Nigeria, 32(2), 166-173.

Philip, M. (2004). Advanced chemistry’ Cambridge university press. ISBN 0521566983 CB2 1RP, United Kingdom.

Ross, S., \& Olivier, J. P. (1964). On physical Adsorption, A clear methods, results and interpretation in the area of physical adsorption interscience publishers, Inc., New York.

\section{Copyrights}

Copyright for this article is retained by the author(s), with first publication rights granted to the journal.

This is an open-access article distributed under the terms and conditions of the Creative Commons Attribution license (http://creativecommons.org/licenses/by/4.0/). 